Steiner, Z., Prakatur, I., Novoselec, J., Samac, D., Klir, Ž., Antunović, B., Benak, S., Gantner, V., Ronta, M. (2020): Influence of pumpkin seed cake on production and slaughter indicators for broiler chickens. Agriculture and Forestry, 66 (3): 25-31.

DOI: $10.17707 /$ AgricultForest.66.3.03

\author{
Zvonimir STEINER ${ }^{I}$, Ivana PRAKATUR ${ }^{I}$, Josip NOVOSELEC ${ }^{I}$, \\ Danijela SAMAC ${ }^{\prime}$ Željka KLIR ${ }^{I}$, Boris ANTUNOVIĆl, \\ Stipo BENAK ${ }^{2}$, Vesna GANTNER ${ }^{1}$, Mario RONTA ${ }^{I}$
}

\title{
INFLUENCE OF PUMPKIN SEED CAKE ON PRODUCTION AND SLAUGHTER INDICATORS FOR BROILER CHICKENS
}

\begin{abstract}
SUMMARY
The aim of the research was to determine the possibility of adding pumpkin seed cake (PSC) in feed mixtures for broiler chickens, as well as its influence on production and slaughter indicators. The experiment consisted of control and two experimental groups of broiler chickens fed for 6 weeks with feed mixtures containing different rates of PSC $(0 \%, 7 \%$ and $14 \%$, respectively). Statistically significantly higher body mass was determined in the E1 group compared to the E2 group $(\mathrm{P}<0.01)$ and in the $\mathrm{E} 1$ group compared to the $\mathrm{C}$ group $(\mathrm{P}<0.05)$. Regarding the percentage shares of different body parts in body weight, the $\mathrm{C}$ and E1 groups had statistically very significantly $(\mathrm{P}<0.01)$ higher values of wing shares compared to the E2 group. Regarding the skin color, L value was statically significantly $(\mathrm{P}<0.05)$ higher in the $\mathrm{C}$ group, compared to the $\mathrm{E} 1$ group. From all of the above, it is to conclude that PSC in the rate of $7 \%$ in fodder mixtures can be recommended for feeding broilers in the period from the 1st until the 42nd day of age, with a potential to improve production and slaughter indicators.
\end{abstract}

Keywords: PSC, feeding, broilers, slaughtering indicators.

\section{INTRODUCTION}

According to the data of the Croatian Bureau of Statistics, the total number of farming poultry heads in the Republic of Croatia in the period from 2012 until 2016 was in average 10 million. Nutritional needs of broiler chickens are very high. In average, feed mixtures contain amino acid ratio and high crude protein level, ranging from $37 \%$ to $48 \%$. As the price of feed participates within the total production cost in the rate of $70 \%$, it is in the interest of farmers to lower this cost. Furthermore, the price of conventional fodders is often unfavourable for producers, so alternative fodders are being sought (Steiner et al., 2015).

\footnotetext{
${ }^{1}$ Mario Ronta, (corresponding author: mronta@fazos.hr), Zvonimir Steiner, Ivana Prakatur, Josip Novoselec, Danijela Samac, Željka Klir, Boris Antunović, Vesna Gantner, Faculty of Agrobiotehnical Sciences Osijek 1, CROATIA.

${ }^{2}$ Stipo Benak, Belje plus d.o.o. CROATIA

Paper presented at the GEA (Geo Eco-Eco Agro) International Conference 2020, Podgorica.

Notes: The authors declare that they have no conflicts of interest. Authorship Form signed online.

Received:29/05/2020

Accepted:30/07/2020
} 
Alternative fodders intended for broiler production are divided to those rich in crude proteins and those rich in energy. PSC is an alternative fodder that has a potential to be a source of protein in poultry due to high levels of crude proteins (Wafar et al., 2017). Pumpkin seed cake (PSC) contains up to $500 \mathrm{~g} / \mathrm{kg}$ of crude proteins and $70 \mathrm{~g} / \mathrm{kg}$ of raw fibre. For the purpose of preparation of meals for monogastric animals, only the pellets and cakes from shelled seeds are being used (Domaćinović 2006).

Fodder produced from shelled seed can be used in feeding swine and older poultry, but despite of large amount of protein, due to the lysine deficiency, it is being used in addition to other protein fodders (Dumovski and Milas, 2004). PSC is a high-quality by-product rich in proteins, derived from pumpkin oil production (Antunović, 2015). Zdunczyk et al. (1999) studied chemical composition and nutritive value of PSC from Cucurbita pepo compared to soybean meal. The content of crude protein and ether extract was higher in PSC compared to soybean meal (598.0 vs. $474.2 \mathrm{~g} / \mathrm{kg}$ and 124.6 vs. $28.3 \mathrm{~g} / \mathrm{kg}$, respectively).

The main fatty acids found in PSC were oleic acid (50.4\%) and linoleic acid (29.9\%). The proteins found in PSC contained significant amounts of tryptophan $(1.54 \mathrm{~g} / 16 \mathrm{~g} \mathrm{~N})$. In contrast, lysine content $(3.21 \mathrm{~g} / 16 \mathrm{~g} \mathrm{~N})$ and isoleucine content $(3.83 \mathrm{~g} / 16 \mathrm{~g} \mathrm{~N})$ were low. Furthermore, small amounts of phenolic compounds $(2.61 \mathrm{~g} / \mathrm{kg})$, low activity of trypsin inhibitor $(1.33 \mathrm{TUI} / \mathrm{mg})$ and small amounts of $\alpha$-galactoside $(19.9 \mathrm{~g} / \mathrm{kg}$ ) were found in PSC. Among the anti-nutritive compounds, only the content of inositol phosphate in PSC (40.5 $\mathrm{mg} / \mathrm{g})$ was higher than in soybean seed $(10.8 \mathrm{mg} / \mathrm{g})$. The simultaneous coefficient of digestibility (TD) of PSC protein was similar (83.1\% vs. $83.5 \%$ ), but the protein efficiency ratio (PER) was lower compared to the soybean meal (1.01 vs. 1.50). Kreft et al. (2002) point out that PSC represents better source than pumpkin seed or pumpkin oil. Also, PSC is a high quality source of high quality fatty acids, proteins, herbal sterols and vitamins.

\section{MATERIAL AND METHODS}

The study included 135 one-day-old broilers of Ross 308 chickens divided into three groups; Control group (C), Experimental group 1 (E1), and Experimental group 2 (E2). The C group fed feed mixtures with no PSC added. The E1 and E2 groups of broilers fed fodder mixtures containing $7 \%$ and $14 \%$ of PSC, respectively.

The feeding itself took place in two phases; the initial - "starter" phase, which lasted for the first 21 days of broiler chickens' life and the final "finisher" phase, which lasted from 22nd until 42nd day of broiler chickens' life. Feeding and watering of chickens was ad libitum. In order to examine the influence of PSC on production and slaughter indicators of broiler chickens, the recipes presented in Table 1 were prepared. 
Table 1. Raw material composition of fodder mixtures

\begin{tabular}{|l|c|c|c|c|c|c|}
\hline \multirow{2}{*}{$\begin{array}{l}\text { Ingredients } \\
\text { \% }\end{array}$} & \multicolumn{2}{|c|}{ C group } & \multicolumn{2}{|c|}{ E1 group } & \multicolumn{2}{c|}{ E2 group } \\
\cline { 2 - 7 } & $\begin{array}{c}\text { Starter } \\
0-21 \mathrm{~d}\end{array}$ & $\begin{array}{r}\text { Finisher } \\
22-42 \mathrm{~d}\end{array}$ & $\begin{array}{c}\text { Starter } \\
0-21 \mathrm{~d}\end{array}$ & $\begin{array}{c}\text { Finisher } \\
22-42\end{array}$ & $\begin{array}{c}\text { Starter } \\
0-21 \mathrm{~d}\end{array}$ & $\begin{array}{c}\text { Finisher } \\
22-42 \mathrm{~d}\end{array}$ \\
\hline Corn meal & 37.2 & 41.3 & 41.7 & 44.2 & 45.8 & 48.4 \\
\hline Barley meal & 11.5 & 10 & 11.5 & 11.5 & 11.5 & 11.5 \\
\hline $\begin{array}{l}\text { Wheat meal } \\
\text { Soybean } \\
\text { meal }\end{array}$ & 5 & 5 & 5 & 5 & 5 & 5 \\
\hline $\begin{array}{l}\text { Pumpkin } \\
\text { seed cake } \\
\text { (PSC) }\end{array}$ & 0 & 0 & 7 & 7 & 14 & 14 \\
\hline $\begin{array}{l}\text { Soybean } \\
\text { meal }\end{array}$ & 21 & 17 & 9.5 & 5.5 & 0 & 0 \\
\hline Plant oil & 1.5 & 3 & 1.5 & 3 & 1.5 & 1.9 \\
\hline $\begin{array}{l}\text { Monocalciu } \\
\text { m phosphate }\end{array}$ & 1 & 1 & 1 & 1 & 1 & 1 \\
\hline Limestone & 1.5 & 1.4 & 1.5 & 1.5 & 1.5 & 1.5 \\
\hline Salt & 0.3 & 0.3 & 0.3 & 0.3 & 0.3 & 0.3 \\
\hline Premixture & 1 & 1 & 1 & 1 & 1 & 1 \\
\hline $\begin{array}{l}\text { Crude } \\
\text { protein }\end{array}$ & 21.07 & 19.88 & 21.16 & 20.00 & 21.16 & 20.00 \\
\hline ME (kcal/kg) & 3000 & 3112 & 3005 & 3105 & 3027 & 3087 \\
\hline Ca (g) & 0.92 & 0.87 & 0.90 & 0.89 & 0.90 & 0.88 \\
\hline P (g) & 0.61 & 0.59 & 0.60 & 0.58 & 0.60 & 0.58 \\
\hline
\end{tabular}

During the experiment, individual weekly weighing of broiler chickens was performed, together with simultaneous monitoring of consumption of feed by groups. Based on the obtained results, weekly weight gains and conversion values in broiler chickens were calculated. After 42nd day of age and after 10-hour of hunger, 10 broiler chickens from each group were sacrificed randomly. For the purpose of this study, the trunks of broiler chickens were weighed and then subtracted to the basic parts; drumstick with thighs, wings, chest and back with pelvis. Each of mentioned body parts were separately weighed. Based on the obtained values, the proportion of basic parts in the trunk was determined and expressed in absolute values $(\mathrm{g})$.

The dressing percentage of chicken carcasses was calculated as the difference between finishing and slaughter weight, and was expressed as a percentage of slaughter weight $(\%)$ in relation to the final fattening mass. For the purpose of testing meat quality, the $\mathrm{pH} 1$ and $\mathrm{pH} 2$ values were measured in chest muscles (within 45 minutes and 24 hours after slaughter, respectively) using the digital $\mathrm{pH}$ meter - Mettler MP 120-B. The colour ( $\mathrm{L}^{*}$ - for the degree of lightness, 
$a^{*}$ - for the degree of redness and $b^{*}$ - for the degree of yellowness) of meat and skin of chickens was determined with Minolta Chromametar CR-410.

The results of the research were analysed by the usage of computer program Statistica 12 (2013). The differences between mean values were tested by GLM (General Linear Model) variance analysis (ANOVA) at significance levels $\mathrm{P}<0.05$ and $\mathrm{P}<0.01$.

\section{RESULTS AND DISCUSSION}

Table 2 represents the weight gain $(\mathrm{g})$ in broiler chickens per week. It is apparent that the groups $\mathrm{C}$ and $\mathrm{E} 1$ had statistically very significantly $(\mathrm{P}<0.01)$ higher weight gain compared to the E2 group in the 1st week of fattening period. In the 2nd week, the trend continued, but without statistically significant differences. In the 3rd week of the experiment, the E1 group had statistically very significantly $(\mathrm{P}<0.01)$ higher weight gain compared to the groups $\mathrm{C}$ and $\mathrm{E} 2$. Within the 4th week, the E1 group had statistically very significantly $(\mathrm{P}<0.01)$ higher weight gain compared to the E2 group. In the 5th week of the experiment, the E1 group had the highest weight gain and together with the $\mathrm{C}$ group statistically very significantly $(\mathrm{P}<0.01)$ higher weight gain compared to the E2 group. In the 6th week, the $\mathrm{E} 1$ group had statistically very significantly $(\mathrm{P}<0.01)$ higher weight gain compared to the $\mathrm{C}$ and $\mathrm{E} 2$ groups.

The obtained results are consistent with the results of Janječić et al. (2016), who investigated the influence of adding PSC to fodder mixtures at rates of 5\% and $10 \%$. Wafar et al. (2017) also found that addition of PSC should not have negative impact on growth rates, although they observed a different trend. In their experiment, increasing of the share of PSC (10\%, 15\% and 20\%) was followed by the increase of total weight gain, while in the group fed by the feed mixture with the lowest level of PSC $(5 \%)$, statistically significant $(\mathrm{P}<0.05)$ lower weight gains were determined.

Table 2. Weight gains ( $\mathrm{g}$ ) in different weeks of fattening broiler chickens

\begin{tabular}{|l|l|l|l|l|l|l|l|}
\hline \multirow{2}{*}{ Week } & \multicolumn{3}{l}{ C group } & \multicolumn{3}{l}{ E1 group } & \multicolumn{2}{l|}{ E2 group } & \multirow{2}{*}{ P value $^{*}$} \\
\cline { 2 - 8 } & $\bar{x}$ & $\mathrm{~s}$ & $\bar{x}$ & $\mathrm{~s}$ & $\bar{x}$ & $\mathrm{~s}$ & \\
\hline $1^{\text {st }}$ & $104.5^{\mathrm{A}}$ & 3.6 & $105.2^{\mathrm{A}}$ & 4.6 & $100.2^{\mathrm{B}}$ & 4.0 & 0.000000 \\
\hline $2^{\text {nd }}$ & 169.6 & 36.0 & 168.8 & 29.2 & 157.2 & 28.2 & 0.123654 \\
\hline $3^{\text {rd }}$ & $283.1^{\mathrm{A}}$ & 39.9 & $307.7^{\mathrm{B}}$ & 42.5 & $271.1^{\mathrm{A}}$ & 26.6 & 0.000048 \\
\hline $4^{\text {th }}$ & 356.6 & 179.1 & $400.9^{\mathrm{A}}$ & 82.6 & $308.7^{\mathrm{B}}$ & 28.9 & 0.001837 \\
\hline $5^{\text {th }}$ & $496.6^{\mathrm{A}}$ & 105.1 & $536.1^{\mathrm{A}}$ & 96.3 & $428.7^{\mathrm{B}}$ & 63.3 & 0.000001 \\
\hline $6^{\text {th }}$ & $578.5^{\mathrm{A}}$ & 102.2 & $718.8^{\mathrm{B}}$ & 168.6 & $604.2^{\mathrm{A}}$ & 100.0 & 0.000001 \\
\hline
\end{tabular}

PSC - pumpkin seed cake

The feed conversion $(\mathrm{kg} / \mathrm{kg})$ per weeks and divided by groups is presented in Table 3. It is apparent that in the 1st week of fattening, the E1 group had 
slightly higher conversion $(1.1 \mathrm{~kg} / \mathrm{kg})$ compared to the C group $(1.08 \mathrm{~kg} / \mathrm{kg})$, while the E2 group had the lowest conversion $(1.05 \mathrm{~kg} / \mathrm{kg})$. In the $2 \mathrm{nd}$ and $3 \mathrm{rd}$ weeks, the highest feed consumption per $\mathrm{kg}$ of body weight gain had the E2 group, whilst the lowest values were found in the $\mathrm{C}$ group. In the period from the 4th week until the end of the experiment, the highest feed consumption was found in the E2 group, whilst the lowest feed consumption was found in the $\mathrm{C}$ group. Overall, the groups E1 and E2 had slightly higher feed consumption per $\mathrm{kg}$ of body weight $(2.08 \mathrm{~kg} / \mathrm{kg})$ compared to the $\mathrm{C}$ group $(1.95 \mathrm{~kg} / \mathrm{kg})$.

The obtained results are partially consistent with the results of Janječić et al. (2016), where feed consumption was the highest in the group fed with $10 \%$ PSC in fodder mixture, which in the same time had the lowest body mass. The group fed fodder mixture with 5\% of PSC had the lowest consumption of feed per $\mathrm{kg}$ of growth, together with lower final body mass than the control group. Martinez et al. (2010) did not notice differences in conversion between the groups. Wafar et al. (2017), obtained results consistent with the results of this experiment

Table 3. Conversion of feed mixture $(\mathrm{kg} / \mathrm{kg})$ in broiler chickens

\begin{tabular}{|l|l|l|l|}
\hline Week & C group & E1 group & E2 group \\
\hline $1^{\text {st }}$ & 1.08 & 1.10 & 1.05 \\
\hline $2^{\text {nd }}$ & 1.09 & 1.12 & 1.21 \\
\hline $3^{\text {rd }}$ & 1.46 & 1.67 & 1.81 \\
\hline $4^{\text {th }}$ & 1.81 & 1.93 & 1.90 \\
\hline $5^{\text {th }}$ & 1.99 & 2.09 & 2.03 \\
\hline $6^{\text {th }}$ & 2.33 & 2.44 & 2.37 \\
\hline Total & 1.95 & 2.08 & 2.08 \\
\hline
\end{tabular}

PSC - pumpkin seed cake

Table 4 presents the differences related to the slaughtering indicators between the groups. The group E1 had statistically very significantly $(\mathrm{P}<0.01)$ higher final body mass compared to the other two groups. The masses of carcasses were the highest in the E1 group in the following way: statistically very significantly higher $(\mathrm{P}<0.01)$ than in the $\mathrm{E} 2$ group and statistically significantly higher $(\mathrm{P}<0.05)$ than in the $\mathrm{C}$ group. The dressing percentage was the highest in the $\mathrm{C}$ group (79\%) and the lowest in the E1 group (76.5\%). There were no statistically significant differences between the groups. The weight of drumsticks with thighs was the highest in the E1 group (565 g) on statistically very significant level $(\mathrm{P}<0.01)$ compared to the $\mathrm{E} 2$ group $(448 \mathrm{~g})$. The breast weight was the highest in the E1 group $(752 \mathrm{~g})$, statistically very significantly $(\mathrm{P}<0.01)$ higher in relation to the E2 group (584 g) and statistically significantly higher $(\mathrm{P}<0.05)$ compared to the $\mathrm{C}$ group $(665.5 \mathrm{~g})$. The wings' weight was statistically very significantly $(\mathrm{P}<0.01)$ higher in the $\mathrm{E} 1$ group $(234 \mathrm{~g})$ than in the other 
groups $(\mathrm{E} 2=209 \mathrm{~g}, \mathrm{C}=210 \mathrm{~g})$. The back weight was statistically very significantly $(\mathrm{P}<0.01)$ higher in the $\mathrm{E} 1$ group $(340 \mathrm{~g})$ compared to the $\mathrm{C}$ group $(315.5 \mathrm{~g})$ and the E2 group $(258 \mathrm{~g})$. The weight of the neck was the highest in the E1 group $(127 \mathrm{~g})$ and statistically very significantly $(\mathrm{P}<0.01)$ higher compared to the E2 group (101.5 g).

The obtained results are consistent with the results of Aguilar et al. (2011) who noticed increased values in the experimental groups fed $3.3 \%$ and $6.6 \%$ of PSC in fodder mixtures, while the group fed $10 \%$ of PSC had lower values of slaughter indicators. Wafer et al. (2017) and Martinez et al. (2010) did not obtain differences in slaughter indicators.

Table 4. Slaughter indicators of broiler chickens

\begin{tabular}{|l|r|r|r|r|r|r|r|}
\hline \multirow{2}{*}{ Indicator } & \multicolumn{2}{l|}{ C group } & \multicolumn{2}{l|}{ E1 group } & \multicolumn{2}{l|}{ E2 group } & \multirow{2}{*}{ P value } \\
\cline { 2 - 7 } & $\bar{x}$ & $\mathrm{~s}$ & $\bar{x}$ & $\mathrm{~s}$ & $\bar{x}$ & $\mathrm{~s}$ & \\
\hline Live weight (g) & $2295.9^{\mathrm{A}}$ & 239.3 & $2636.7^{\mathrm{B}}$ & 225.9 & $2078.3^{\mathrm{A}}$ & 113.2 & 0.000005 \\
\hline Carcass weight (g) & $1813.5^{\mathrm{a}}$ & 200.3 & $2018.0^{\mathrm{A} . \mathrm{b}}$ & 190.1 & $1600.5^{\mathrm{b} . \mathrm{B}}$ & 117.4 & 0.000052 \\
\hline Dressing percent \% & 79 & 9.4 & 76.5 & 6.6 & 77.01 & 7.9 & 0.430796 \\
\hline $\begin{array}{l}\text { Drumstick with } \\
\text { thigh weight (g) }\end{array}$ & 508.5 & 62.9 & $565.0^{\mathrm{A}}$ & 58.4 & $448.0^{\mathrm{B}}$ & 42.1 & 0.000280 \\
\hline Brest weight (g) & $664.5^{\mathrm{a}}$ & 82.8 & $752.0^{\mathrm{b} . \mathrm{A}}$ & 74.5 & $584.0^{\mathrm{b} . \mathrm{B}}$ & 50.4 & 0.000062 \\
\hline Wings' weight (g) & $210.0^{\mathrm{A}}$ & 8.2 & $234.0^{\mathrm{B}}$ & 15.8 & $209.0^{\mathrm{A}}$ & 12.0 & 0.000106 \\
\hline Back weight (g) & $315.5^{\mathrm{A}}$ & 57.4 & $340.0^{\mathrm{A}}$ & 44.0 & $258.0^{\mathrm{B}}$ & 29.0 & 0.001166 \\
\hline Neck weight (g) & 115.0 & $20.7^{\mathrm{B}}$ & $127.0^{\mathrm{A}}$ & 18.3 & $101.5^{\mathrm{B}}$ & 4.7 & 0.005994 \\
\hline
\end{tabular}

\section{CONCLUSIONS}

Based on the obtained results, it can be concluded that PSC can be used as a substitute of quality for soybean meal in feeding broiler chickens. However, there are certain limitations related to quantity. Better results were achieved with smaller share (7\%) of PSC in fodder mixture. After adding higher levels of PSC (14\%), a bit worse production results were achieved, both in growth rates and in slaughtering indicators.

\section{REFERENCES}

Antunović, Z., Novoselec, J., Sičaja, V., Stainer, Z., Klir, Ž., \& Matanić, I. (2016). The use of pumpkin seed cake in the diets of lambs in organic farming. Krmiva: Časopis o hranidbi životinja, proizvodnji i tehnologiji krme, 57(1), 3-9.

Aguilar, Y. M., Yero, O. M., Navarro, M. I. V., Hurtado, C. A. B., López, J. A. C., \& Mejía, L. B. G. (2011). Effect of squash seed meal (Cucurbita moschata) on broiler performance, sensory meat quality, and blood lipid profile. Brazilian Journal of Poultry Science, 13(4), 219-226.

Domaćinović, M. (2006). Hranidba domaćih životinja. Poljoprivredni fakultet u Osijeku. 
Dumovski, F., Milas, Z, (2004). Priručnik o proizvodnji i upotrebi stočne hrane krme. Hrvatsko agronomsko društvo, Zagreb.

Državni zavod za statistiku https://www.dzs.hr/ 13. 04. 2018

Janječić, Z.,Bedeković, D., Pintarić, J., Babić-Alagić, J. (2016): Upotreba pogače sjemenki bundeve u hranidbi brojlera. Zbornik sažetaka 23. međunarodnog savjetovanja Krmiva 2016. 1-2 lipnja., Opatija, Hrvatska, str 80.

Kreft, I., Stibilj, V., \& Trkov, Z. (2002). Iodine and selenium contents in pumpkin (Cucurbita pepo L.) oil and oil-cake. European Food Research and Technology, 215(4), 279-281.

Martínez, Y., Valdivié, M., Martínez, O., Estarrón, M., \& Córdova, J. (2010). Utilization of pumpkin (Cucurbita moschata) seed in broiler chicken diets. Cuban Journal of Agricultural Science, 44(4), 387-392.

Statisitica-Stat Soft, Inc. Version 12, 2013, www.statsoft.com

Steiner, Z., Domaćinović, M., Klarić, I., Ronta, M., Bertić, V., Steiner, N., \& Šerić, V. (2015). Procjena upotrebe ddgs-a u krmnim smjesama tovnih pilića. Krmiva: Časopis o hranidbi životinja, proizvodnji i tehnologiji krme, 56(4), 163-167.

Wafar, R. J., Hannison, M. I., Abdullahi, U., \& Makinta, A. (2017). Effect of Pumpkin (Cucurbita pepo L.) Seed Meal on the Performance and Carcass Charac teristics of Broiler Chickens. Asian Journal of Advan ces in Agricultural Research, 2(3), 1-7.

Zdunczyk, Z., Minakowski, D., Frejnagel, S., \& Flis, M. (1999). Comparative study of the chemical composition and nutritional value of pumpkin seed cake, soybean meal and casein. Food/Nahrung, 43(6), 392-395. 